\title{
HERODOTUS AND EGYPTIAN WOMEN: THE CONSTRUCTION OF FEMALE BEHAVIORS IN THE SECOND LOGOS OF HISTORIES
}

\author{
Nathalia Monseff Junqueira ${ }^{1}$
}

\begin{abstract}
Aiming at the presentation of new possibilities in studying the women in the Classical Antiquity involving the discussions of the Cultural History, gender studies, identity and subjectivity of the historical subjects, we have chosen as a source of such article the work of Herodotus from Halicarnassus, the Greek historian, who wrote Histories in the fifth century B.C. Our intention is to analyze the selected passages in Book II in which the Egyptian women are presented in several situations, searching for evidences that this historian would support an ideal of a woman which could be part of the imaginary of a great deal of the Greek male population. Thus, we intend to demonstrate the way female behavior is represented in our source and how varied feminist social practices could be present in the same imagined would for women in ancient world.
\end{abstract}

\section{Keywords}

Egypt; Greek; Ancient History; gender, Herodotus.

\footnotetext{
${ }^{1}$ Assistant Professor, Federal University of Mato Grosso do Sul, Corumbá, Brazil.

E-mail: nathmj@gmail.com
} 


\section{Resumo}

Com o objetivo de apresentar novas possibilidades de se estudar as mulheres na Antiguidade Clássica, englobando as discussões da História Cultural, estudos de gênero, identidade e subjetividade dos sujeitos históricos, escolhemos como fonte para esse artigo a obra do historiador grego Heródoto de Halicarnasso, que escreveu Histórias no V a.C. Nossa intenção é a de analisar as passagens que selecionamos no Livro II em que as mulheres egípcias são relatadas em diversas situações, procurando evidências de que esse historiador compartilharia de um ideal de mulher que poderia fazer parte do imaginário de uma parcela da população masculina ateniense. Assim, demonstramos a maneira como esse padrão de comportamento feminino aparece na nossa fonte e como outras práticas sociais femininas poderiam habitar o mesmo mundo imaginado para as mulheres no mundo antigo.

\section{Palavras-chave}

Egito; Grécia; História Antiga, gênero, Heródoto. 


\section{Initial considerations}

According to Keith Jenkins (2005:23), discourses do not create the world, but they "appropriate the world and give it all its meanings." Based on this premise, we will seek in this article to interpret Herodotus' representation of Egyptian women in his Histories, for in this document we can observe how the category of feminine and the expected behavior for those women were constructed through political, cultural and social interaction which permeated Athenian society.

The choice of the second book of this work, which describes Egypt, was due to the fact that Herodotus explained that the Egyptians would have different customs from all other peoples (II, 35), as well as to describe, in a more detailed way, those customs. Thus, to examine our working hypothesis, that the Greek historian would share with a portion of the Athenian male population a pattern of behavior that women should follow, we have decided to select some more significant passages from that work in which the Egyptian women are reported. Our selection of these passages was largely based on the possibility of dialogue with the expectation of the construction of feminine and masculine social roles in the ancient society and that the decisions to report certain events, on the part of Herodotus, would reinforce an ideal of woman which should be followed by them. That is, the choices he makes throughout the story would not be a random action. What we want is, from the analysis of these passages, to interpret the mechanism used by Herodotus to relate those women, through his selection of the events to be described and, at the same time, to show that he had the opportunity to visualize other feminine practices in the Athenian society, which are considered in his narrative only in few moments.

\section{Herodotus: trajectory and work}

Historians have, unfortunately, little information about the life of Herodotus and the writing of his work, Histories. In his only work that has been preserved, he makes no mention of the particular matters of his life. According to David Asheri (Ashery; Lloyd; Corcella, 2007:01), we know only his name and his hometown by the first words written in the prologue of his work:

Here is the exposition of the investigations of Herodotus of Halicarnassus so that the deeds of mankind will not be lost in time, and that the great and admirable enterprises of both barbarians and Greeks will not remain 
unrecognized; and, above all, the reason why they fought against each other. (Moraes, 1999:12)

Herodotus would have been born between the years of $484-480 \mathrm{BC}^{2}$ in Halicarnassus, present-day Bodrum, and region of Turkey. Halicarnassus was originally a Carian and Doric city. The city had an intense commercial life due to the trade of products made through its port (Hart, 1982:159). He would have lived among the main Greek conflicts of the fifth century BC: first, the Persian Wars (499-479 BC), war between the Greeks and Persians, and the Peloponnesian War (431-404 BC), war between the poleis group led by Athens against the group led by Sparta. There is not much information about the early years of his life. As tradition says, he was exiled from his homeland for having united in opposition to Lygdamis, seeking refuge in Samos, a city that was an autonomous member of the League of Delos since $478 \mathrm{BC}$. He returned to Halicarnassus after the coup that would have removed Lygdamis from power, what seems to have taken place in the year 454 BC (Waters, 1996:10; Ashery; Lloyd; Corcella, 2007:03). After this period, Herodotus would have traveled through various regions near the Mediterranean Sea and the Red Sea; he would be in Athens in 445-4 and then he would have left for Thurii, where he became a citizen, dying approximately in the 420s BC.

These journeys by Herodotus and the intention of understanding the motives that led the Greeks and Persians to war have resulted in the work entitled Histories, written in Ionic dialect, in a simple and direct style (Waters, 1996:28). These journeys, in the beginning, would not have the specific purpose of a historical research (Ashery; Lloyd; Corcella, 2007:07), and we do not know when Herodotus conceived the idea of composing his Histories or some literary composition, as Hart affirms $(1982: 162)$.

\footnotetext{
2 The first data that generates disagreement among the historians through the reading we did is what refers to the date of birth of Herodotus. According to K. H. Waters (1996:10), A. D. Godley (1990:vii), John Hart (1982:158) and John L. Myres (1999:03) it would have been in $484 \mathrm{BC}$. On the other hand, there are scholars who accept other dates: Cynthia Morais (2004:15) and François Hartog (1999:32) opted for the date of 480 BC, and Claude Orrieux and Pauline Pantel, of 485 BC (2004:221). For Waters (1996:10), the date of $484 \mathrm{BC}$ would have been chosen because the approximate maturity period of the Greek historian's life, conventionally the age of 40 years old, is tied to Thurii's foundation date (an event dated in 444-3 BC) and, therefore, the date of his birth was calculated. Asheri (Ashery; Lloyd; Corcella, 2007:05) informs us of another calculation for the date of the birth of Herodotus: according to ancient authors, Herodotus was 53 years old when the Peloponnesian War broke out in $431 \mathrm{BC}$, that is, adding the two dates, we will have the year $484 \mathrm{BC}$.
} 
The region where Halicarnassus was located allowed a meeting of Greek and Oriental culture, and this contact provided the flourishing of rational and inquisitive thinking, making it possible for philosophers to seek a different understanding from that afforded by myth for the manifestations of nature (Morais, 2004:20). The first application of rational thought would have been made by Thales of Miletus in the year $585 \mathrm{BC}$ in the prediction of an eclipse.

Waters (1996:23) states that this prediction was possible because Thales was aware of the astronomical observations made by the Babylonians, which were the basis of his study. This Ionian region has also produced results in fields beyond philosophy. Through the knowledge of geometry of the Egyptians, Anaximander produced, in 499 BC, the first map of the world. We can thus see how the Eastern influence served as the basis for the development of the sciences in the Greek world. This influence of rationality is present in Herodotus, since the translation of the word totopia ${ }^{3}$, title of the work, is investigation. As Arnaldo Momigliano points out (2004:60), the Greek historian chose to record the customs and events of various peoples through the critical examination of that record, when he believed it was appropriate. This rationality is present, for example, in the passage from his trip to Egypt, when he decides to measure, with the help of the guides, the pyramid of Khafre. (Hdt., II, 127)

We must, at this moment, pay attention to the fact that Herodotus has written Histories in Ionic, not in Carian or Dorian language, common languages in his polis. He would be acquainted with this dialect, which was used in official documents of the time, and recognized as a literary language since Homer (Waters, 1996:26; Ashery; Lloyd; Corcella, 2007:03). Halicarnassus was a port city, as we have already mentioned, and may therefore have suffered a linguistic and cultural influence from Northern Ionian communities. However, as Godley points out (1990:16), Herodotus also made use of many words and forms that are associated with Attic literature. For the author, perhaps, the stay of the Greek historian in Athens may have influenced the writing of his text. On the other hand, the use of the words written in old Ionic and Attic becomes, in some moments, so similar that it is difficult to perceive clearly the dividing line between them.

The events narrated in his work can also help us to establish the beginning and end dates of the writing process by which the historian

\footnotetext{
3 The word toropia only came to mean the study of the events of the past after the fourth century BC (Ashery; Lloyd; Corcella, 2007:08), that is, a century after Herodotus.
} 
went through and would end in the events described in the first two years of the Peloponnesian War (431-30 BC) which leads us to believe that he stopped writing soon after these events. According to tradition, Herodotus certainly had been in Athens for the public reading of his work, which was the form of publication of the works at that time, in 445$4 \mathrm{BC}$, receiving for this the exorbitant sum of 10 talents (Momigliano, 2004:66; Morais, 2004:15; Ashery; Lloyd; Corcella, 2007:04).

Myres (1999:12) points out that perhaps the work was not complete when the reading for the Athenian Boule took place. Herodotus must have written the main body of his work around 440-30 BC4 - and, according to Momigliano (2004:67), this may have happened in Athens - a considerable period for the insertion of other logoi which Herodotus believed important to achieve the purpose of his composition. At this point, we must emphasize that the audience of the work should have been the Hellenic public, and this fact could influence how the work was thought and composed, and how he would describe certain societies, customs, laws and also women, the latter being the focus of this article.

Many historians disagree with the moment the work has been divided into nine books. According to Asheri (Ashery; Lloyd; Corcella 2007:11), it was in the medieval manuscript tradition that this division took place, each book receiving a name of a muse, following the canonical order founded by Hesiod: Clio, Euterpe, Thalia, Melpomeni, Terpsichore, Erato, Polymnia, Ourania and Calliope. For François Hartog (1999:33) the name of the Muses is not attested as the title of the books of Herodotus before the second century $\mathrm{AD}$, and he goes on to say that this inclusion of the Muses demonstrates how the Greek historian's text was received: "it's beside... of poetry, pleasure and fiction."

In his work, Herodotus approaches different subjects - not only political ones, but also with regard to the constructions and customs of other peoples - that, at certain moments, end up making the reader wonder what the purpose of the text is. At times, we have the impression that Herodotus had written logoi separately which were later grouped together, often showing abrupt cuts between one book and another.

In the context of the fifth century $\mathrm{BC}$, the only possible historical narrative to be elaborated was that of immediate knowledge, a history of present time, according to Jorge Lozano (1994:19). The historian narrates what he saw with his own eyes or reports the events from someone who has

\footnotetext{
${ }^{4}$ For Cynthia Morais (2004:15), the work would have been written around 446-5 or 445$4 \mathrm{BC}$.
} 
witnessed them. This statement of Lozano is evident in this passage taken from the Egyptian logos: "So far, what has been said derives from what I saw, judged and investigated; from now on, I'm going to talk about the Egyptian stories I've heard and I've added something I've seen myself" (Hdt., II, 99 In: Moraes, 1999:177). For Momigliano (2004:62), Herodotus makes clear in his narrative the boundary between personal observations, I have seen, and his oral sources, I have heard.

If Herodotus were considered a traveler, it should not be surprising that the passages found in his narrative arose from both his own vision and his hearing. As for oral reports, according to Lozano (1994:19), one might suppose that they would not have the same weight as personal testimony, for the memory of this other person would sometimes be unreliable. But the Greek historian at times reinforces the credibility of his sources, noting, where appropriate, that his informant is able to describe that type of information. This position, says Momigliano (2004:63), is one of the most characteristic points of the critical method used by Herodotus.

However, as Pedro Paulo Funari stresses (2003:18), we must be aware of the intrinsic subjectivity of the historical narrative from the moment of the conception that "all knowledge necessarily expresses itself as a discourse", emphasizing even more the concern in knowing who is the author and to whom the work is intended. Regarding Jean-Pierre Vernant's reasoning (2010:55), one of the characteristics of the Athenian polis was the publicity of knowledge that was previously restricted to family traditions, or to texts that circulated little among the population. Returning to the historians' assertion that Herodotus read his discourse to the Athenians, we may infer that his intended audience was the Hellenics, not the peoples reported in his work.

\section{The description of the female characters in the Egyptian logos}

The second book of Histories tells the reader at the outset that Cambyses, the son of the Persian king Cyrus, had inherited the empire from his recently deceased father, and from the moment he would gather all the army and the slaves conquered by his father, would carry out a military expedition against Egypt (II, 1). This passage reminds us of information elaborated by historiography on the political context of the region in the fifth century BC: Cambyses would have invaded Egypt in $525 \mathrm{BC}$ and the Persians would have been in power since that period. 
After dwelling on political matters, Herodotus goes on to describe the Nile River, the arable land, the territorial extension of the land of the Pharaohs and its frontiers until, in chapter thirty-five, to make explicit the choice of Egypt as a place to be known and reported in his work: "While the Egyptian climate is different, the river presents a nature contrary to that of other rivers, and in fact many laws and customs establish themselves contrary to those of other men" (Hdt., II,35). From this passage, we find several moments in which Egyptian women are represented in diverse historical and social contexts. We selected some important passages for the analysis of our working hypothesis in this article, however, we emphasize that the Egyptian women appear in several chapters of the second book.

We hypothesize that Herodotus, in registering female behavior in the regions he visited, uses a Greek cultural filter, accentuating the significant differences between the Hellenic world and other peoples, that is, as Hartog points out (1999:229) "the world in which one speaks and the world that is spoken about". We must emphasize the fact that he may have read his work in public in Athens, that is, his narrative would have a particular audience, the Hellenes, and the way he would describe the women could not disprove the opinions of his audience.

The first section selected concerns the social roles men and women played in the Egyptian region:

On the one hand, women go to the agora and accomplish the trade, on the other hand, the men who stay at home weaving (...) women urinate standing, men do it sitting (...) the woman cannot be priestess of no god or goddess, men can be priest of both. Sons have no obligation to feed their parents if they do not want to, while daughters are under an obligation to feed them, even if they do not want to. (II 35-36).

According to Donald Lateiner (1989:147), what marks the ethnographic report that the historian makes in Book II, in chapters 1 to 99 is precisely the polarity in his investigations, coming to affirm that all the "herodotean logoi are ethnocentric, with the Greeks at the center of the analysis". For Alan B. Lloyd (Ashery; Lloyd; Corcella, 2007:219), the distinction between the Greeks and the barbarians, and in this case the Egyptians, is in the employment of the perception of cultural differences that are not judged or disapproved by the author. When Herodotus, in the passage II, 35, states that the Egyptians, their customs and river regimes differ from all other peoples, the Greek historian only informs his audience of these differences. From this premise, he exposes the differences between the roles played by men and women in Egypt, even stating that women urinated standing or were engaged in commerce, 
which was, for the Athenians, a behavior that should be practiced only by men.

This description enables us to demonstrate that in reporting the Egyptian woman, we can imagine, in an opposite way, what role Greek women should play in their society. Herodotus would carry Greek elements on his journey, and this influence would permeate all the ethnographic descriptions of his work, as Richard McNeal points out (1988:54). This behavior of the women could serve as an example of the lack of Greek characteristics in the Egyptians, as Lateiner states (1989:149). There is a system of comparison in which Greek culture is compared to Egyptian culture, and the values and motivation of Greek individuals are reiterated to his Hellenic audience to each new counterpoint. Herodotus makes explicit these cultural and social differences between these two peoples when he states that the Egyptians "avoid adopting the customs of the Hellenes. In fact, they avoid any custom of any other people". (Hdt., II, 91).

Analyzing Herodotus' discourse, we can imagine the Athenian women taking into account McNeal's statement (1988:71) that the Herodothean work explains much more Greek culture than that of other peoples. In describing the Egyptian women, considering the question of Hartog's otherness (1999:316), he reconstructs, from an inversion movement, the Athenian woman, who does not go to the market, because she would stay at home weaving. For this, it is necessary that the comparison be made by elements known in his world, the Hellenic, establishing between the two parts of the comparison, similarities and differences. In this case, we perceive only differences between the Greek and the Egyptian world, between the self and the other.

The masculine and feminine roles, which should be performed within the polis, are constituted by the characteristics that permeate each gender at that moment. According to Marta Mega de Andrade (2003:116), social identities are "shaped by the attribute of gender". Lourdes Feitosa (2005:22) complements this statement, because for her this behavior, which each gender should play, is influenced by the cultural relations articulated between them. In other words, the present discourse in society polarizes the genres and adds antagonistic characteristics to them, there being a fabrication of gender, but that only occurs through the relationship between men and women within that society. Perhaps it is for this reason that the Greek historian adds a masculine attribute to women - they urinate standing - and feminine to men - men, sitting. At the end of this passage, by the inversion of the roles, we delineate how 
the genders were related within the Athenian polis, because in the discourse it is evident what the social procedure of each one.

The activities concerning women in the time of Herodotus were those less visible, such as those confined within the houses. According to Sara Pomeroy (1999:90-91), women of the wealthier classes could not work; his duty was to worry about keeping the house and taking care of the children. Her circle of contact with people include, beyond her husband and children, her parents, sisters, some close relatives, and servants. The image of the women prisoners in a room that was reserved to her, the so called gynoecium, at the moment is no longer accepted. However, for this author, they had few relationships with the outside world. For Gould (1980:48), wealthy Athenian women would have a slave who would do the service for which it was necessary to leave the house, such as fetching water from the springs, thereby preventing the Athenian women from meeting unknown men, who could pose, according to Fantham et al. (1994:103), a threat to her chastity and legitimation of heirs.

Although rigorous exclusion had rarely been practiced, as Pomeroy states (1999:89), it is clear that both ideologically and in real life, the house was the predominant sphere of women's work. However, female domestic labor was considered to have a low social value. From the moment a work was depreciated, so was the one who performed it. The work of the women was productive, but, being similar to the one of the slaves, it ended up not being valued. Women were set to spin and weave, works that they had all learned from their mothers and were part of the education of a future wife who would guard her domestic slaves. The inversion of the attributes belonging to men and women is also evident in the passage selected at the moment Herodotus describes that the weaving work would be in the hands of the Egyptian men.

If we considered only this passage of Herodotus, we would believe that the Athenian women would remain in the house, taking care of their domestic tasks. However, although women of the wealthier strata are rarely represented outside the houses, they are present at festivals, cemeteries, and marriages (Fantham et al, 1994:79). For not being strange the participation of women in funeral rituals in Herodotus' eyes, he describes how such rituals were performed in Egypt, without making explicit his opinion on this subject:

Their songs of mourning and funerals are as follows: among them, when a man of an important family dies, all the women of the house anoint the head or face with mud, then after leaving the corpse at home, they wander around the city striking themselves, with their clothes up to their waist and show their breasts. (II, 85) 
Mortuary cults have been present in the decorations of various Egyptian tombs since the Old Kingdom. According to Asheri, although sources about the rituals performed after the death of a relative are much earlier than Herodotus, "it is perfectly plausible that such a practice, or at least a general tendency, existed in the fifth century BC." (Ashery; Lloyd; Corcella, 2007:298)

We agree with Sue Blundell (2001:126) when she states that Athenian women could also be seen in funerary rituals. In this case, according to Fantham et al. (1994:76-7), Solon would also have regulated how this ritual should be conducted, and that only close relatives of the deceased could guard it, also recommending restraint in lamentation in public; in other words, an attempt to curtail the contact of women with other men separated from their family circle.

In chapter 92 of Book II, Herodotus comes back to comparing Hellenes and Egyptians, stating that "those who inhabit the wet marshes of Egypt practice the same customs as the other Egyptians, and among others, each of them lives with only a woman, as the Hellenes..." (II, 92) Asheri states that Herodotus chose to narrate "a standard practice rather than a full range of legal options that would occur in Egypt." (Ashery; Lloyd; Corcella, 2007:304)

According to the historiography about Classical Greece, cohabitation is necessary to make the young daughter a gamete gune, a single legitimate wife, as described by Herodotus. Marriage is never a free choice on the part of the young woman, especially in situations where there would be an agreement between families. The purpose of marriage was the procreation of legitimate children destined to inherit maternal goods, and it was therefore bound up with the system of ownership and succession of assets. (Mossé, 1991:52)

However, these rules of behavior were not always followed, and norms were created to determine the punishments applicable to adulterous men and women. The Greek word moicheia, or adultery, as Blundell points out (1994:125) has many meanings. It could be translated as maintaining unauthorized love affairs with women who had an Athenian guardian and who did not work as courtesans or companions. According to the author mentioned above (1994:125), men did not have the freedom to sexually relate to anyone they wanted, being moicheia an offense punishable. If a citizen took a man in the sexual act with a woman under his tutelage, he had the right to kill him at that moment. Another possibility for the lover would be to offer financial compensation - which would make him a prisoner until he provided the guarantees of the 
agreed sum between them - to the other man, or he could still inflict various bodily humiliations on the lover. If the tutor did not succeed in catching the couple in the act, or if he had decided not to take any particular action, he would still have the option of suing the lover for seduction or rape.

Athenian laws thus sought to regulate the love life of its population. According to Fantham et al. (1994:73), Athenian men could have and they had concubines. However, after Pericles' citizenship law of 451-450 BC, children with concubines would no longer have the right to attend assemblies or official religious rituals of the polis. Thus, the law would guarantee legitimate children the maintenance of their political rights, which could be considered one of the distinctions between the legitimate woman and the concubine within the Athenian polis.

This question involving the children who would be legitimate, and thus could participate in political life, refers us to the last selected passage. Herodotus, in chapter 99, announces that from that moment he would tell "the reports of the Egyptians, as I have heard from them" (II, 99). From that moment on, the author begins to describe the History of Egypt, beginning with the first pharaoh, Min (Menes). Among his words, some information catches the eye: "Among so many generations of men ... a single born queen ... The name of this woman, who has the same name as that who reigned in the territory of Babylon, was Nitocris5." (II, 100).

Probably a queen in Egypt would also have aroused Herodotus' curiosity. The Athenian democracy, political system contemporary to the period of writing of the Histories, excluded women from voting and entering the assembly. This democratic citizenship, as defined during the Age of Pericles, excluding women from political power, does not exhaust the possibilities of intimate relationship with the polis, such as the generation of legitimate children and the maintenance of the memory of the ancestors.

It is not only the fact that a woman can hold the highest political office of a society that stands out in this passage, but also the attitude that Queen Nitocris, according to the report of the Egyptian priests, undertakes to avenge the death of her brother by the Egyptians. Thus says Herodotus:

\footnotetext{
${ }^{5}$ When consulting various works that have dealt with Herodotus' narrative, we may infer that he probably must have been confused about the name of the queens, or a translation error between the pharaoh's account and the understanding of the translator who would assist Herodotus. In any case, the origin of Nitocris does not cancel her importance for the making of the Histories and for our analysis in this article.
} 
... she built a huge underground enclosure and ... formulated other intentions in her mind; and she invited the Egyptians to this place ... receiving many guests, as they feasted, the river advanced by a huge hidden channel. They did not report other events, except that she, after that fact, threw herself into a room full of ashes to avoid revenge. (Hdt., II, 100)

In the words of the Greek historian, we can note that Nitocris crafted an ingenious revenge, which required planning and time to be executed, plotted other intentions in her mind, and showed no repentance for the Egyptians' death. At no point in this passage do we find the opinion of the priests on this episode. According to the words of Ove Strid (2006:403), Herodotus is interested in the circumstances surrounding the death of the victim, avoiding narrating the point of view of the victim. The important thing is to describe the process of the death, especially if it is extraordinary and marvelous, there being no difference whether the death occurred on the battlefield or by revenge.

\section{Final considerations}

We can see in these Egyptian scenes the construction of cultural codes mediated by representations of social roles across the attributions granted to men and women in different places and historical contexts. By Herodotus' account, it was possible to infer many other information about the Egyptian women: that they wore only a garment (II, 36), that is, a linen garb which is represented in the iconography of the Egyptian tombs; that they traded their goods on the market (II, 35); that they participated in funeral rites (II, 85) and could even become queens (II, 100). At the same time, these descriptions allow us to demonstrate - in reporting the Egyptian woman, we can imagine, in an opposite way what role Greek women should play in their society, since the Greek historian would carry Greek elements in his journey through the regions of the inhabited world.

We believe that the passages selected for this text are permeated by the resources of the construction of the other and, in this way, we are able to delineate the parameter of a female behavior, in which Athenian women should observe in their daily lives, through the description of the performance of Egyptian women. However, from the narrative of Herodotus, we can also perceive the diversity of feminine practices within the societies described by him.

This little sketch of the Egyptian logos in the Histories alerts us to the idea that women would have a defined behavior in the Athenian society and 
that it should be adopted in the families and respected by women themselves. However, we do not believe that Athenian women had a passive behavior in relation to their presence in the public sphere, and if we accept the theory of some historians that Herodotus had lived in Athens for some years, it would not be surprising for him to find women exercising other activities outside the oikos in this polis. But the content of his report reinforces our working hypothesis, that he adopts a model of female behavior to be followed by women.

In this way, we perceive that the gender roles constructed by the masculine discourse in the case of the Antiquity, in which it is stipulated that each sex, according to its physical characteristics, is responsible for specific tasks within the city-state, such as the weaving for women and the trade for men, not always condition women's actions practiced in the different social spheres. In other words, historians, when analyzing their sources, must pay attention to the plurality of male and female performances in the societies studied. (Sebillotte-Cuchet; Ernoult, 2006: 12)

Thus, Scott (1986:1056) invites us to reflect on the different practices of men and women in different historical contexts and on their relationships established within a given society. The gender category, as the author affirms (1986:1054), allows us to affirm that this feminine ideal behavior is born of the mediations between men and women in society and that will result in the definition of which social roles are assigned to each of the sexes in a specific context. In this text, we do not seek to show how these genres are represented in the discursive productions, since we cannot consider that men and women lived completely in separate spheres in Athenian society.

The study of gender in the Egyptian logos of Herodotus revealed to us, from the theme of otherness, the range of identities and constructions of social roles within Athenian society, which are discourses pervaded by subjectivity and power relations (Funari, 2008:102-3), which must be read and interpreted by historians. According to Jenkins (2005:33), we know the past through the questions we ask our present, that is, history is a constantly changing discourse, for the emergence of new cultural symbols (Scott, 1986:1074) provokes new reinterpretations of the past. Thus, the conclusions presented in this article constitute a way of interpreting the ancient sources, even those that have already been scrutinized by several researches throughout the centuries, as is the case of the Histories, elaborated by the father of History. 


\section{Bibliographical references}

\section{Greek sources}

HERODOTE. Introduction, notice preliminaire sur la vie et la personnalité d'Herodote et sur la presente edition par E. Legran. Paris, Belles Lettres, 1932.

HERODOTUS. With an English translations by A. D. Godley. Cambridge, Mass.; London: Harvard Univ.: Heinemann, 1990.

\section{Reference works}

ANDRADE, Marta Mega de. A "Cidade das Mulheres": a questão feminina e a polis revisitada. In: FUNARI, Pedro Paulo; FEITOSA, Lourdes Conde; SILVA, Glaydson José da (Orgs.). Amor, desejo e poder na Antigüidade: relações de gênero e representações do feminino. Campinas: Editora da Unicamp, 2003.

ASHERI, David; LLOYD, Alan; CORCELLA, Aldo. Herodotus Books I-IV. Oxford, Oxford University Press, 2007.

BLUNDELL, Sue. Women in ancient Greece. Cambridge, Mass.: Harvard University Press, 1995.

BRIANT, Pierre. From Cyrus to Alexander: A history of the Persian Empire. Winona Lake, Indiana: Eisenbrauns, 2002.

Hérodote et la société perse. In: REVERDIN, Olivier; GRANGE, Bernard. Hérodote et les peuples non grecs. Genève: Vandoeuvres, 1988.

FANTHAM, Elaine; FOLEY, Helene Peet; KAMPEN, Natalie Boymel; SHAPIRO, H. A. Women in the Classical World. New York: Oxford University Press, 1994.

FEITOSA, Lourdes Conde. Amor e Sexualidade: o masculino e o feminino em grafites de Pompéia. São Paulo: Ed. Annablume, 2005.

FUNARI, Pedro Paulo A. Antiguidade Clássica - a história e a cultura a partir dos documentos. Campinas, Ed. Unicamp, 2003.

Gênero e conflitos no Satyricon: O caso da Dama de Éfeso. História: Questões e Debates, Curitiba, n. 48/49, p. 101-117, 2008. Editora UFPR. 
GOULD, John. Law, Custom and Myth: Aspects of the Social Position of Women in Classical Athens. The Journal of Hellenic Studies, Vol. 100, Centenary Issue, p. 38-59, 1980. Acesso em: 12/08/2010.

HART, John. Herodotus and Greek History. New York: St. Martin's Press, 1982.

HARTOG, François. O espelho de Heródoto: ensaio sobre a representação do outro. Belo Horizonte: Editora UFMG, 1999.

HERÔDOTOS. História. Tradução do grego, introdução e notas de Mário da Gama Kury. Brasília: Ed. Universidade de Brasília, 1985.

HERÓDOTO: Histórias: O relato clássico da Guerra entre Gregos e Persas. Trad. J. Brito Broca. São Paulo: Ediouro, 2001.

JENKINS, Keith. A História repensada. São Paulo: Ed. Contexto, 2005.

LATEINER, Donald. The Historical Method of Hedorodus. Toronto: University of Toronto Press, 1989.

LOZANO, Jorge. El discurso histórico. Madrid: Alianza Editorial, 1994.

MCNEAL, Richard A. The Brides of Babylon: Herodotus 1.196. Historia: Zeitschrift für Alte Geschichte, Vol. 37, n. 1, p. 54-71, 1st Qtr., 1988.

MOMIGLIANO, Arnaldo. As raízes clássicas da historiografia moderna. Trad. Maria Beatriz B. Florenzano. Bauru, S.P.: EDUSC, 2004.

MORAIS, Cynthia. Maravilhas do Mundo Antigo: Heródoto, pai da História? Belo Horizonte: Editora UFMG, 2004.

MORAES, Érica Siane. Heródoto e o Egito. Tradução e comentário do Livro II das Histórias. Dissertação de Mestrado. Campinas, 1999.

MOSSÉ, Claude. La femme dans la Grece Antique. Bruxelles: Éditions Complexes, 1991.

MYRES, John L. Herodotus, father of history. Oxford: Clarendon Press: Sandpiper Books, 1999 (1953).

ORRIEUX, Claude; PANTEL, Pauline Schmitt. Histoire grecque. Paris: Presses universitaires de France, 2004.

POMEROY, Sara B. Diosas, rameras, esposas y esclavas: mujeres en la Antigüedad Clásica. Madrid: Ediciones Akal, 1999. 
SCOTT, Joan. Gender: A useful category of historical analysis. The American Historical Review. Vol. 91, n. 5, p. 1053-1075, Dec., 1986.

SEBILLOTTE-CUCHET, Violaine; ERNOULT, Nathalie. Problèmes $d u$ genre en Grèce ancienne. Paris: Publications de la Sorbonne, 2007.

TRID, Ove. Voiceless victims, memorable deaths in Herodotus. Classical Quarterly, vol. 52, n. 2, p. 393-403, 2006.

VERNANT, Jean-Pierre. As Origens do Pensamento Grego. Rio de Janeiro: Editora Difel, 2010.

VIVERO, Manuel Albaladejo. Crueldad y violencia en los personajes femeninos de Heródoto. Emerita, vol. LXXV, n. 2 (julio-diciembre), 2007, p. 299-317.

WATERS, K. H. Heródoto El historiador. México, Fundo de Cultura Economica, (1985) 1996. 